\title{
Direct evidence of sea anemone predation on Arctic echinoids
}

\author{
Tomasz Borszcz $^{1} \cdot$ Piotr Balazy ${ }^{1}$
}

Received: 29 December 2014 / Revised: 12 March 2015 / Accepted: 20 March 2015 /Published online: 12 April 2015

(C) The Author(s) 2015. This article is published with open access at Springerlink.com

Predator-prey interactions are considered a major evolutionary driver and a key biological factor affecting recent organisms, but little is known about their influence on Arctic benthic life. It is not easy to document predatorial behaviour in situ in the marine realm, especially in polar seas, and thus usually only indirect evidence is available. Palaeoecologists use several proxies to infer predation on echinoids (Wilson et al. 2015), namely drill holes, repair scars, ejecta deposits

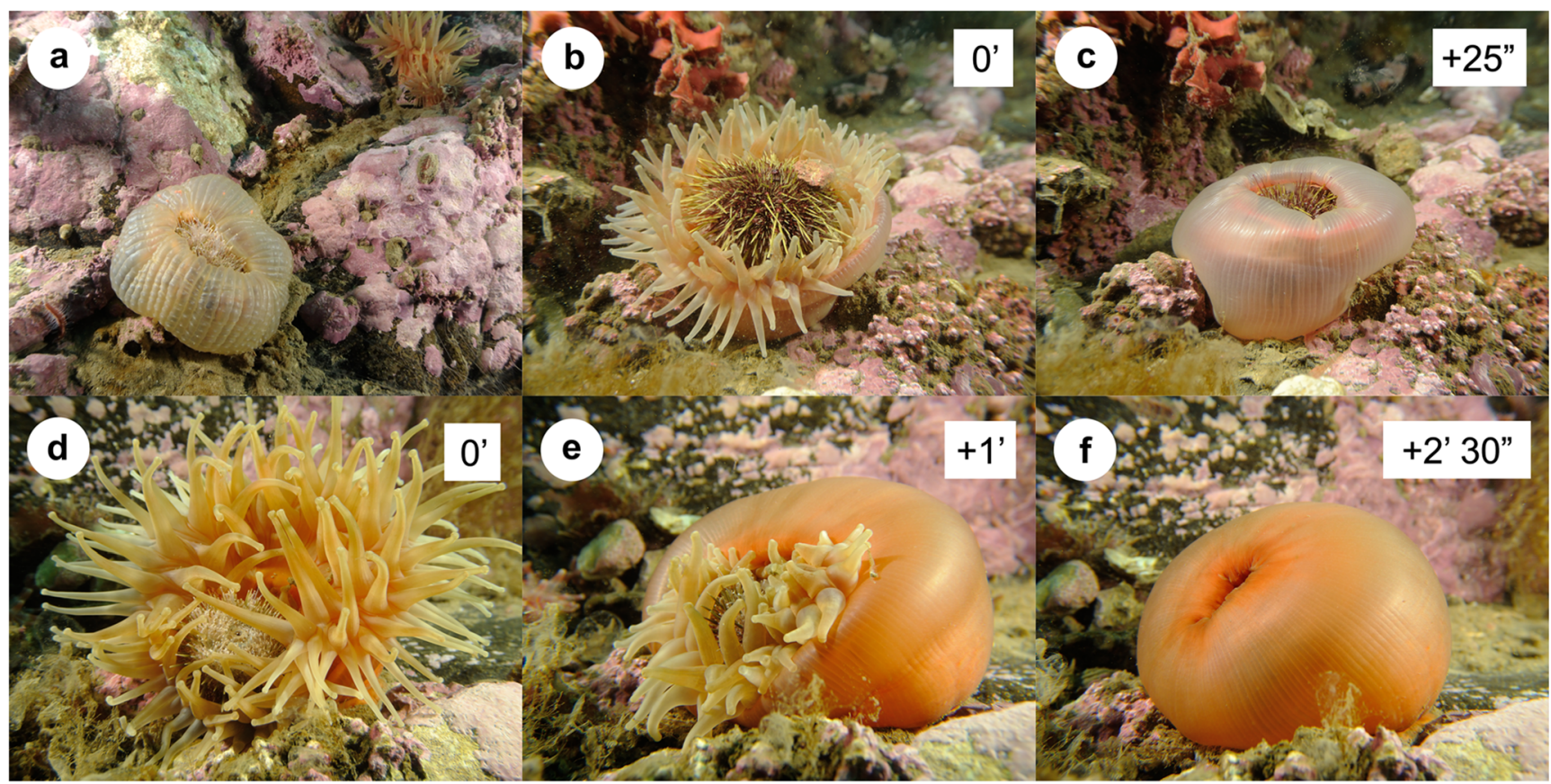

Fig. 1 Cribrinopsis similis ingesting Strongylocentrotus droebachiensis encountered in situ (a). The two time-sequences (b-c and d-f) of photographic trials demonstrate predatory behaviour. Sea urchins diameter 5-6 cm

Communicated by B. W. Hoeksema

$\triangle$ Tomasz Borszcz

tomekb@iopan.gda.pl

1 Institute of Oceanology, Polish Academy of Sciences, Powstancow Warszawy 55, Sopot 81-712, Poland 
(regurgitates), or bite marks. However, these are not adequate for predators such as sea anemones.

Two actiniarians representing different species, Urticina crassicornis and Cribrinopsis similis (http://www.iopan.gda. $\mathrm{pl} /$ projects/biodaff/actiniaria/index.html), were observed while SCUBA diving in July 2013 and July 2014 on the rocky bottom of an Arctic fjord, Isfjorden (Spitsbergen; $\left.78^{\circ} 11^{\prime} 18.0^{\prime \prime} \mathrm{N}, 15^{\circ} 08^{\prime} 41.1^{\prime \prime} \mathrm{E}\right)$, with partially, or almost completely denuded, echinoid tests inside their polyps (Fig. 1a). Around these predators, empty tests were found, which eventually may disintegrate into small fragments (ossicles) that leave no macroscopic sign of predation. To confirm whether echinoids constitute possible prey for the investigated sea anemones, multiple series of underwater photographs were taken at 10-15 $\mathrm{m}$ depth. Each time (Fig. 1b-c, d-f) large-sized echinoids (Strongylocentrotus droebachiensis) were offered, the sea anemones immediately embraced the prey with their tentacles, closed, and began ingestion (Fig. 1b-f).

Kortsch et al. (2012) reported that green sea urchins in nearby fiords are involved in a long-term predatory interaction with the actiniarian Urticina eques and ascidian Halocynthia pyriformis, resulting in an inverse relationship of abundance as a response to rising seawater temperature. These echinoids are key boreal-Arctic herbivores, which have several natural antagonists apart of actiniarians (Scheibling and Hatcher 2001). Given our evidence from Isfjorden and those from elsewhere (Gulliksen et al. 1980), it is likely that actiniarianechinoid interactions could be much more widespread taxonomically and geographically, and thus of more than regional importance.

Acknowledgments Katarzyna Zmudczyńska-Skarbek, Piotr Kukliński, and Tadeusz Stryjek helped in the field while reviewers and Editor improved the text. START scholarships (FNP), Mare Incognitum (RIS 6575, MNiSW- E13WS025) and the NFR Marine Night (226417) provided support.

Open Access This article is distributed under the terms of the Creative Commons Attribution 4.0 International License (http:// creativecommons.org/licenses/by/4.0/), which permits unrestricted use, distribution, and reproduction in any medium, provided you give appropriate credit to the original author(s) and the source, provide a link to the Creative Commons license, and indicate if changes were made.

\section{References}

Gulliksen B, Haug T, Sandnes OK (1980) Benthic macrofauna on new and old lava grounds at Jan Mayen. Sarsia 65:137-148

Kortsch S, Primicerio R, Beuchel F, Renaud PE, Rodrigues J, Lønne OJ, Gulliksen B (2012) Climate-driven regime shifts in Arctic marine benthos. Proc Natl Acad Sci U S A 109:14052-14057

Scheibling RE, Hatcher BG (2001) The ecology of Strongylocentrotus droebachiensis. In: Lawrence JM (ed) Edible sea urchins: biology and ecology, vol 32, Dev Aquac Fish Sci., pp 271-306

Wilson MA, Borszcz T, Zatoń M (2015) Bitten spines reveal unique evidence for fish predation on Middle Jurassic echinoids. Lethaia 48:4-9 